\title{
Indirect Assessment of Program Student Outcomes Through Student's Learning Experiences at the Faculty of Engineering
}

\author{
Dedison Gasni ${ }^{1, *}$ Haznam Putra ${ }^{2}$
}

\author{
${ }^{1}$ Mechanical Engineering Department, Faculty of Engineering, Universitas Andalas, Padang, Indonesia \\ ${ }^{2}$ Mechanical Engineering Department, Faculty of Engineering, Universitas Andalas, Padang, Indonesia \\ *Corresponding author. Email: dgasni@eng.unand.ac.id
}

\begin{abstract}
This paper is to investigate the relationship between the learning experiences of students and achieving program student outcomes (PSOs) based on ABET Accreditation of undergraduate study programs at the Faculty of Engineering Universitas Andalas. A questionnaire consisted of seven PSOs, which represent learning experiences of student's knowledge, skills, and behavior in 21 questions that were distributed to 177 students. It is found that the learning experiences of students in achieving PSOs between males and females were different except for the ability of students in communication, teamwork skills, and experimentation. Civil and Mechanical Engineering students have the highest achievement of PSOs through their learning experiences.
\end{abstract}

Keywords: Learning experiences, Program students outcomes, Indirect assessment

\section{INTRODUCTION}

Program student outcomes (PSOs) are defined as the knowledge, skills, abilities, or attitudes that students have at the end of their study before getting a degree or certificate. Study programs have generated PSOs based on the requirements of internal and external stakeholders. In engineering programs, PSOs have been established by the Engineering Accreditation Commission (EAC) of the Accreditation Board for Engineering and Technology (ABET), which is consisted of seven PSOs [1]. Faculties try to design the teaching and learning process to make sure that PSOs can be achieved by students after their learning. The humanistic education theory states that (1) the learners' perceived meaningfulness of a learning experience as an essential measure of the educational outcomes, and that (2) the leaners are a legitimate evaluator of his learning. A course, perceived meaningfulness, and value are related to the perceived learnings in the cognitive- subject matter, affective-personal, and behavioral domain [2,3]. According to $[4,5,6]$ the quality of learning outcomes is determined by the approaches to learning. The study conducted by [6] with nursing students shows that the deep approach of learning leads to better quality learning outcomes. Based on the student's perception, the deep approach was associated with excellent teaching, choice of ways to learn, openness to the views of students, and the student center learning could encourage a deep approach to learning [7].

To make sure that students can achieve the PSOs, study programs might conduct the assessment. Assessment is conducted not only to measure student achievement of PSOs [8] but also to prepare for further study in the program, to encourage and document faculty dialogue about student learning and achievement, to help faculty with program improvement, and to communicate and clarify our expectations to students. PSOs can be assessed in many ways, such as assessment trough linked course level outcomes (CLOs), where faculty might assess PSOs in a capstone project and could assess development a set of skills of students. These kinds of assessments are based on direct evidence of student learning, which we called direct assessment methods [9]. This method is tangible, visible, and measurable 
and tends to be more compelling evidence of exactly what students have and have not learned.

In the other hand, indirect assessments of student learning ascertain the perceived extent or value of learning experiences. Amongst indirect methods are surveys, exit interviews, focus groups, and the use of external reviewers. They assess opinions or thoughts about student knowledge or skills. Indirect measures can provide information about student perception of their learning and how this learning is valued by different constituencies [10]. An indirect assessment is useful in that it can be used to measure certain implicit qualities of student learning, such as values, perceptions, and attitudes, from a variety of perspectives [11]. However, in the absence of direct evidence, assumptions must be made about how well perceptions match the reality of the actual achievement of student learning. Indirect methods can flesh out areas that direct assessments cannot capture.

\subsection{Learning Experience}

Based on experiential learning theory, it says that learning as a process whereby knowledge is created through the transformation of experience [11]. Learning experience refers to any interaction, course, and program. Learning experience not only occurs in the classroom and outdoor environments, but also it includes students learning from teachers and professors or through games and interactive software applications. Besides that, learning experience may also be used to reinforce the goal of an educational interaction of learning.

The use of the term learning experiences is growing that reflects larger pedagogical and technological shifts. In the design and delivery of education to students, the shifts have occurred; new technologies have dramatically multiplied and diversified how students can learn from and interact with educators and learning independently through the learning management system (LMS). Students can use software programs, videos created by teachers, apps, and educational games to learn on their own time and their own pace. Listening to a lecture, reading a book, and completing homework are ways learning experiences in the past, but students are now learning in a different way and a wide variety of outside of the school of setting, such as internship and volunteer activities.

\subsection{Assessment Methods}

Assessment of student outcomes in higher education involves a variety of methods, such as direct, indirect, quantitative, and qualitative, to measure students' achievement and provides adequate feedback to the program to identify strengths and weaknesses of the curriculum [12]. In general, there are two types of assessment: direct and indirect. Direct assessment is the evaluation of student work or performance, for example, exams, reports, presentations. Indirect assessment is the evaluation of data that would imply achievement without directly observing the student or students' work product, for example, student selfassessment, employer focus groups, or retention, graduation, and placement rates.

At the program level and at the course level, both direct and indirect assessment requires a significant effort on the part of faculty, and it is often difficult to leverage the data to test the impact of curricular innovations over time. Curricular workgroups were engaged in course-based direct assessment and how the process was utilized to achieve consistency amongst courses taught by different educators. That effort was successful in developing a documented process, and this process was being used at the course level to track improvements overtime at the course level. However, as evidence of student learning, indirect measures are not as strong as direct measures because assumptions must be made about what precisely the self-report means. If students report that they have attained a particular learning outcome, how can that report be validated?. An indirect assessment is useful in that it can be used to measure certain implicit qualities of student learning, such as values, perceptions, and attitudes, from a variety of perspectives [9]. However, in the absence of direct evidence, assumptions must be made about how well perceptions match the reality of the actual achievement of student learning.

It is important to remember that all assessment methods have their limitations and contain some bias. A meaningful assessment program would use both direct and indirect assessments from a variety of sources (students, alumni, faculty, employers, etc.). This use of multiple assessment methods provides converging evidence of student learning. Indirect methods provide a valuable supplement to direct methods and are generally a part of a robust assessment program [9].

\subsection{Program Student Outcomes}

Program student outcomes (PSOs) describe what students are expected to know and able to do by the time of graduation (skills, knowledge, and behaviors). The engineering study programs of Universitas Andalas have adopted PSOs of ABET (1) to (7) for their program student outcomes, as listed in Table 1.

\subsection{Performace Indicators}

Each PSOs is associated with two or more performance indicators (PIs) describing the characteristics, skills, knowledge, attitudes, and/or values that students exhibit to demonstrate 
achievement of the PSOs. PIs are a means for faculty to articulate the program-specific interpretation of each ABET outcome relative to the engineering study programs at the faculty of engineering Universitas Andalas and are not additional criteria that students must meet. The achievement of PSOs is accomplished by the successful demonstration of at least one performance indicator. The list of PIs presented in Table 2 was informed by learning activities and course learning outcomes of individual courses in the engineering study programs at Universitas Andalas. It is anticipated that PIs may change over time as part of the continuous improvement process. The assessment system is designed to incorporate changes in PIs without diminishing our ability for longitudinal assessment of PSOs achievement.

In this paper, we investigated how to make sure that the program student outcomes (PSOs) can be achieved by students through their learning experiences as long as the learning process. This study based on a survey carried out to engineering students at the Faculty of Engineering Universitas Andalas.

Table 1 PSOs of engineering study programs

\begin{tabular}{|c|c|c|}
\hline No & Program Student Outcomes (PSOs) [1] & $\begin{array}{l}\text { Skills, Knowledge, and } \\
\text { Behaviour }\end{array}$ \\
\hline 1. & $\begin{array}{l}\text { an ability to identify, formulate, and solve complex engineering problems by } \\
\text { applying principles of engineering, science, and mathematics }\end{array}$ & $\begin{array}{l}\text { Engineering foundation and } \\
\text { complex problem solving }\end{array}$ \\
\hline 2. & $\begin{array}{l}\text { an ability to apply engineering design to produce solutions that meet } \\
\text { specified needs with consideration of public health, safety, and welfare, as } \\
\text { well as global, cultural, social, environmental, and economic factors }\end{array}$ & Design \\
\hline 3. & an ability to communicate effectively with a range of audiences & Communication \\
\hline 4. & $\begin{array}{l}\text { an ability to recognize ethical and professional responsibilities in } \\
\text { engineering situations and make informed judgments, which must consider } \\
\text { the impact of engineering solutions in global, economic, environmental, and } \\
\text { societal contexts }\end{array}$ & $\begin{array}{l}\text { Professional responsibility } \\
\text { and broad education }\end{array}$ \\
\hline 5. & $\begin{array}{l}\text { an ability to function effectively on a team whose members together provide } \\
\text { leadership, create a collaborative and inclusive environment, establish } \\
\text { goals, plan tasks, and meet objectives }\end{array}$ & Teamwork \\
\hline 6. & $\begin{array}{l}\text { an ability to develop and conduct appropriate experimentation, analyze and } \\
\text { interpret data, and use engineering judgment to draw conclusions }\end{array}$ & Experimentation \\
\hline 7. & $\begin{array}{l}\text { an ability to acquire and apply new knowledge as needed, using appropriate } \\
\text { learning strategies }\end{array}$ & New knowledge \\
\hline
\end{tabular}

Table 2 Performance indicators (PIs) for each program student outcomes (PSOs)

\begin{tabular}{|c|c|c|}
\hline No. & $\begin{array}{c}\text { Skills, Knowledge, and } \\
\text { Behaviour }\end{array}$ & Performance Indicators (PIs) \\
\hline 1. & $\begin{array}{l}\text { Engineering Foundation Complex and problem } \\
\text { solving }\end{array}$ & $\begin{array}{l}\text { a. Students are able to use math to solve problems } \\
\text { in the engineering field. } \\
\text { b. Students are able to use engineering science in } \\
\text { formulating a problem in the field of } \\
\text { engineering. } \\
\text { c. Students are able to solve and formulate a } \\
\text { complex problem. }\end{array}$ \\
\hline 2. & Design & $\begin{array}{l}\text { a. Students are able to do a design concept by } \\
\text { considering health, safety, welfare, global, } \\
\text { cultural, environmental, economic factors } \\
\text { b. Students are able to Functional decomposition } \\
\text { c. Students demonstrate the ability to create a } \\
\text { prototype and to do tests. }\end{array}$ \\
\hline
\end{tabular}




\begin{tabular}{|c|c|c|}
\hline 3. & Communication & $\begin{array}{l}\text { a. Students are able to create graphical things to } \\
\text { explain something in the engineering field. } \\
\text { b. Students demonstrate the ability to do an } \\
\text { c. Sral presentation. } \\
\text { Students are able to make a technical } \\
\text { report }\end{array}$ \\
\hline 4. & $\begin{array}{l}\text { Professional responsibility and } \\
\text { broad education }\end{array}$ & $\begin{array}{l}\text { a. Students are able to use code and standard when } \\
\text { they design } \\
\text { b. Students are able to show their professional } \\
\text { responsibility as an engineer. } \\
\text { c. Students are able to show their awareness by } \\
\text { considering impact engineering solutions in } \\
\text { global, economic, environmental, and societal } \\
\text { contexts. }\end{array}$ \\
\hline 5. & Teamwork & $\begin{array}{l}\text { a. Students are able to work in project planning and } \\
\text { show their leadership. } \\
\text { b. Students are able to contribute and interact in } \\
\text { teamwork with their colleagues in solving } \\
\text { engineering problems. } \\
\text { c. Students are able to use new tools in solving } \\
\text { engineering problems or projects. }\end{array}$ \\
\hline 6. & Experimentation & $\begin{array}{l}\text { a. Students are able to design and build an } \\
\text { experimentation } \\
\text { b. Students are able to conduct an } \\
\text { experiment } \\
\text { c. Students are able to analyze and interpret data. }\end{array}$ \\
\hline 7. & New knowledge & $\begin{array}{l}\text { a. Students are able to know the current event of } \\
\text { the engineering field. } \\
\text { b. Students demonstrate the abilities to study in } \\
\text { independent learning } \\
\text { c. Students are able to know the emerging } \\
\text { technologies in the engineering field. }\end{array}$ \\
\hline
\end{tabular}

\section{METHODS}

A cross-sectional study was used to measure of achieving PSOs through student's learning experiences as long as the learning process at the faculty of engineering Universitas Andalas. A survey-based on the perception of students regarding their learning experiences was developed to make sure that POs are achieved. The students were asked to choose a number on a scale from 1-7: 1 as least favorable, 7 as most favorable.

The research hypotheses for this research are as follows:

H1: There are differences between males and females in achieving PSOs through their learning experiences

$\mathrm{H} 2$ : There are differences amongst study programs in achieving PSOs through their learning experiences

H3: Which PSOs are different amongst study programs in achieving PSOs through their learning experiences

\subsection{Sampling}

The sample included 177 students from five study programs (Mechanical Engineering, Civil Engineering, Industrial Engineering, Electrical Engineering, and Environmental Engineering) at the Faculty of Engineering Universitas Andalas. All students, at least in the 8th semester who were active in odd semester Y2019/2020 were asked to participate. Of the 707 students, $177(25,05 \%)$ agreed to take part and completed the questionnaire that met our quality criteria for inclusion in the final sample. The respondence included more males (62.15\%) than females and consisted of 65 Mechanical Engineering students, 30 Civil Engineering students, 29 Industrial Engineering students, and 28 Environmental Engineering students. 


\subsection{Reability and Validity Analysis}

To guaranty that the instrument is reliable, the reliability and validity analysis were conducted. The reliability of the experiment is achieved when an experiment gives the same results repeatedly [13]. From the analysis, the value of Cronbach's coefficient was 0,93, and according to Murphy and Balzer [14], the value of Cronbach's coefficient of above 0.7 is considered suitable and reliable.

\section{RESULTS AND DISCUSSION}

\subsection{Demografic Profiles and Frequency}

Table 3 Demographics of survey respondent
The number of students in the population, Frequency, and percent of each of the demographic features are shown in Table 3. The total respondents were 177 students who come from 5 study programs. $62.15 \%$ of the total respondents were male, and $37.85 \%$ were female.

This research was conducted using a structured questionnaire with 21 questions to measure student's perceptions of their learning experiences. The learning experiences of students are measured to achieve PSOs, which have three dimensions, namely: skill, knowledge, and behavior. All of the PSOs were covered with 21 questions which represent performance indicators, and the structure of the questionnaire is shown in Table 4.

\begin{tabular}{|l|c|c|c|}
\hline \multicolumn{1}{|c|}{ Demographic features } & Demographic features & Frequency & Percent \\
\hline Study Programs: & & & \\
1. Mechanical Engineering & 159 & $65(8)$ & $36.72 \%$ \\
2. Civil Engineering & 205 & $30(14)$ & $16.95 \%$ \\
3. Industrial Engineering & 108 & $29(8)$ & $16.38 \%$ \\
4. Electrical Engineering & 143 & $25(19)$ & $14.13 \%$ \\
5. Environmental Engineering & 92 & $28(18)$ & $15.82 \%$ \\
Total & $\mathbf{7 0 7}$ & $\mathbf{1 7 7}(\mathbf{6 7})$ & $\mathbf{1 0 0 . 0 0 \%}$ \\
\hline Gender: & & & \\
1. Male & 456 & 110 & $62.15 \%$ \\
2. Female & 251 & 67 & $37.85 \%$ \\
Total & $\mathbf{7 0 7}$ & $\mathbf{1 7 7}$ & $\mathbf{1 0 0 . 0 0 \%}$ \\
\hline
\end{tabular}

Table 4 PSOs consisted of skill, knowledge, and behavior and questions in the questionnaire

\begin{tabular}{|c|l|c|}
\hline No. & \multicolumn{1}{|c|}{ PSOs (Skills, Knowledge, and Behaviour) } & Questions \\
\hline 1. & Engineering foundation and complex problem solving & $1-3$ \\
\hline 2. & Design & $4-6$ \\
\hline 3. & Communication & $7-9$ \\
\hline 4. & Professional responsibility and broad education & $10-12$ \\
\hline 5. & Teamwork & $13-15$ \\
\hline 6. & Experimentation & $16-18$ \\
\hline 7. & New knowledge & $19-21$ \\
\hline
\end{tabular}

\subsection{Results of Learning Experiences in Achieving PEOs Based on Sex}

The perception of students in achieving PEOs based on learning experiences between males and females was compared by using a t-test. Table 5 shows that there are significant differences obtained between males and females in achieving PEOs with $p=0,028$. The average total PSOs achievement of the male is higher than that of the female where male are 5,54 while female are 5,29 .

If we saw more detail from PSOs were consist of 7 SOs. In general, the PSOs can be grouped in skill, knowledge, and behavior. From Table 6, we can see that $\mathrm{SO} 3, \mathrm{SO}$, and SO6 are no differences in the learning experiences of students between males and females with $\mathrm{p}>0,05$. It means that communication ability (SO3) and teamwork (SO5) well-knowns as skills are no differences between males and females. The otherwise cognitive ability of males was higher than that of females.

From Table 7, it shows that on SO1, only PI 3 was not significantly different between male and female. The same cases in SO2 and SO4, where PI 4 and PI 10, respectively, were not significant based on sex with $\mathrm{p}>$ 0,05 . 
Table 5 The average total of achieving PSOs based on sex

\begin{tabular}{|c|c|c|c|}
\hline Program Student Outcomes (PSOs) & Male & Female & $\boldsymbol{p}$ \\
\hline Total & $5,54 \pm 0,71$ & $5,29 \pm 0,76$ & 0,028 \\
\hline
\end{tabular}

Table 6 The average of each PSOs based on sex

\begin{tabular}{|c|c|c|c|}
\hline Student Outcomes & Male & Female & $\boldsymbol{p}$ \\
\hline SO 1 & $5,51 \pm 0,754$ & $5,18 \pm 0,836$ & 0,007 \\
\hline SO 2 & $5,15 \pm 1,012$ & $4,66 \pm 1,102$ & 0,003 \\
\hline SO 3 & $5,95 \pm 0,917$ & $6,02 \pm 0,756$ & 0,624 \\
\hline SO 4 & $5,54 \pm 0,921$ & $5,18 \pm 0,945$ & 0,013 \\
\hline SO 5 & $5,73 \pm 0,839$ & $5,72 \pm 0,877$ & 0,919 \\
\hline SO 6 & $5,38 \pm 1,106$ & $5,19 \pm 0,997$ & 0,246 \\
\hline SO 7 & $5,51 \pm 0,937$ & $5,08 \pm 0,929$ & 0,004 \\
\hline
\end{tabular}

Table 7 The average of each PIs based on sex

\begin{tabular}{|c|c|c|c|}
\hline Performance Indicators (PIs) & Male & Female & $p$ \\
\hline PI 1 & $5,41 \pm 1,025$ & $5,04 \pm 1,224$ & 0,035 \\
\hline PI 2 & $5,55 \pm 0,797$ & $5,18 \pm 1,086$ & 0,009 \\
\hline PI 3 & $5,58 \pm 1,128$ & $5,33 \pm 1,006$ & 0,133 \\
\hline PI 4 & $5,35 \pm 1,154$ & $4,99 \pm 1,331$ & 0,053 \\
\hline PI 5 & $5,06 \pm 1,152$ & $4,58 \pm 1,304$ & 0,011 \\
\hline PI 6 & $5,03 \pm 1,337$ & $4,40 \pm 1,346$ & 0,004 \\
\hline PI 7 & $6,11 \pm 0,932$ & $6,30 \pm 0,817$ & 0,172 \\
\hline PI 8 & $5,85 \pm 1,195$ & $5,79 \pm 0,962$ & 0,713 \\
\hline PI 9 & $5,90 \pm 1,108$ & $5,97 \pm 0,969$ & 0,669 \\
\hline PI 10 & $5,40 \pm 1,175$ & $5,15 \pm 1,184$ & 0,171 \\
\hline PI 11 & $5,75 \pm 0,999$ & $5,24 \pm 1,156$ & 0,002 \\
\hline PI 12 & $5,48 \pm 1,139$ & $5,15 \pm 1,062$ & 0,055 \\
\hline PI 13 & $5,99 \pm 0,873$ & $5,96 \pm 1,079$ & 0,810 \\
\hline PI 14 & $5,71 \pm 0,961$ & $5,61 \pm 1,141$ & 0,545 \\
\hline PI 15 & $5,49 \pm 1,147$ & $5,58 \pm 1,032$ & 0,595 \\
\hline PI 16 & $5,15 \pm 1,141$ & $5,00 \pm 1,101$ & 0,542 \\
\hline PI 17 & $5,53 \pm 1,224$ & $5,31 \pm 1,131$ & 0,248 \\
\hline PI 18 & $5,46 \pm 1,055$ & $5,25 \pm 1,035$ & 0,198 \\
\hline
\end{tabular}




\begin{tabular}{|c|c|c|c|}
\hline PI 19 & $5,69 \pm 1,011$ & $5,27 \pm 1,009$ & 0,008 \\
\hline PI 20 & $5,35 \pm 1,184$ & $4,93 \pm 1,132$ & 0,021 \\
\hline PI 21 & $5,50 \pm 1,155$ & $5,06 \pm 1,127$ & 0,014 \\
\hline
\end{tabular}

\subsection{Results of Learning Experiences Based on Study Programs}

The research used a one-way ANOVA test to investigate what the average total learning experiences of PEOs were impacting on study programs. Before one-way ANOVA test was conducted, the homogeneity test was conducted first. The result of the homogeneity test $(p>0,05)$ shows that the data distribution of the group was normal. Table 8 shows the results of a oneway ANOVA test. Civil Engineering has the highest average total of PSOs, whereas Industrial Engineering has the lowest one. There were significant differences in the average total of PEOs amongst study programs with $\mathrm{p}<0,003$.

If we see more detail for each PSOs as shown in Table 9, SO3, SO5, and SO7 were not different amongst study programs with $\mathrm{p}>0,05$. It means that soft skills ability (communication and teamwork skills) and experimentation of students were not significant differences.

Table 10 shows 21 PIs that represent the learning experiences of students. From the table, it shows that PI 7, PI 8, PI 9, PI 13, PI 14, PI 20, and PI 21 were not different amongst study programs.

Table 8 The average total of PSOs based on study programs

\begin{tabular}{|c|c|c|c|c|c|c|}
\hline PSOs & Mechanical Eng. & Civil Eng. & Electrical Eng. & Industrial Eng. & Environ. Eng. & $\boldsymbol{p}$ \\
\hline Total & $5,62 \pm 0,69$ & $5,71 \pm 0,93$ & $5,21 \pm 0,58$ & $5,19 \pm 0,66$ & $5,25 \pm 0,63$ & 0,003 \\
\hline
\end{tabular}

Table 9 The average differences of each PEOs based on study programs

\begin{tabular}{|c|c|c|c|c|c|c|}
\hline PSOs & Mechanical Eng. & Civil Eng. & Electrical Eng. & Industrial Eng. & Environ. Eng. & $p$ \\
\hline SO1 & $5,61 \pm 0,73$ & $5,62 \pm 1,04$ & $5,17 \pm 0,63$ & $5,01 \pm 0,73$ & $5,21 \pm 0,66$ & 0,001 \\
\hline SO2 & $5,33 \pm 1,00$ & $5,23 \pm 1,18$ & $4,64 \pm 0,97$ & $4,63 \pm 1,16$ & $4,45 \pm 0,70$ & 0,000 \\
\hline SO3 & $6,04 \pm 0,86$ & $6,01 \pm 1,00$ & $5,76 \pm 0,85$ & $5,97 \pm 0,67$ & $6,02 \pm 0,91$ & 0,734 \\
\hline SO4 & $5,53 \pm 0,85$ & $5,87 \pm 1,14$ & $4,93 \pm 0,87$ & $5,16 \pm 0,83$ & $5,30 \pm 0,88$ & 0,002 \\
\hline SO5 & $5,87 \pm 0,84$ & $5,92 \pm 0,99$ & $4,45 \pm 0,70$ & $5,59 \pm 0,83$ & $5,57 \pm 0,79$ & 0,105 \\
\hline SO6 & $5,48 \pm 1,01$ & $5,70 \pm 1,22$ & $5,27 \pm 0,71$ & $4,83 \pm 1,20$ & $5,01 \pm 0,92$ & 0,007 \\
\hline SO7 & $5,46 \pm 0,89$ & $5,58 \pm 1,12$ & $5,25 \pm 0,85$ & $5,12 \pm 1,01$ & $5,17 \pm 0,91$ & 0,242 \\
\hline
\end{tabular}

Table 10 Differences average of each PIs based on study programs

\begin{tabular}{|c|c|c|c|c|c|c|}
\hline PIs & $\begin{array}{c}\text { Mechanical } \\
\text { Eng. }\end{array}$ & Civil Eng. & Electrical Eng. & Industrial Eng. & Environ. Eng. & $p$ \\
\hline PI 1 & $5,63 \pm 0,86$ & $5,23 \pm 1,50$ & $5,28 \pm 0,74$ & $4,72 \pm 1,31$ & $5,04 \pm 1,12$ & 0,004 \\
\hline PI 2 & $5,54 \pm 0,79$ & $5,63 \pm 1,25$ & $5,00 \pm 0,82$ & $5,31 \pm 1,04$ & $5,36 \pm 0,73$ & 0,082 \\
\hline PI3 & $5,66 \pm 1,09$ & $6,00 \pm 1,08$ & $5,24 \pm 0,97$ & $5,00 \pm 1,10$ & $5,25 \pm 0,89$ & 0,002 \\
\hline PI 4 & $5,46 \pm 1,05$ & $5,50 \pm 1,57$ & $4,56 \pm 1,26$ & $5,17 \pm 1,34$ & $4,96 \pm 0,84$ & 0,013 \\
\hline PI 5 & $5,18 \pm 1,21$ & $5,30 \pm 1,26$ & $4,56 \pm 0,92$ & $4,59 \pm 1,34$ & $4,32 \pm 1,02$ & 0,002 \\
\hline PI 6 & $5,34 \pm 1,30$ & $4,90 \pm 1,52$ & $4,80 \pm 1,08$ & $4,14 \pm 1,53$ & $4,07 \pm 1,09$ & 0,000 \\
\hline PI 7 & $6,20 \pm 0,87$ & $6,47 \pm 0,94$ & $5,96 \pm 0,94$ & $6,14 \pm 0,74$ & $6,07 \pm 0,98$ & 0,276 \\
\hline PI 8 & $5,86 \pm 1,10$ & $5,80 \pm 1,24$ & $5,64 \pm 1,11$ & $5,79 \pm 1,11$ & $6,00 \pm 0,90$ & 0,831 \\
\hline
\end{tabular}




\begin{tabular}{|c|c|c|c|c|c|c|}
\hline PI 9 & $6,05 \pm 0,99$ & $5,77 \pm 1,36$ & $5,68 \pm 0,90$ & $5,97 \pm 0,98$ & $6,00 \pm 1,05$ & 0,552 \\
\hline PI 10 & $5,45 \pm 1,12$ & $5,90 \pm 1,30$ & $4,76 \pm 1,05$ & $5,07 \pm 1,10$ & $5,07 \pm 1,12$ & 0,002 \\
\hline PI 11 & $5,68 \pm 0,97$ & $5,97 \pm 1,16$ & $5,16 \pm 1,14$ & $5,21 \pm 1,08$ & $5,54 \pm 1,07$ & 0,021 \\
\hline PI 12 & $5,46 \pm 1,03$ & $5,73 \pm 1,31$ & $4,88 \pm 0,93$ & $5,21 \pm 1,24$ & $5,29 \pm 1,01$ & 0,056 \\
\hline PI 13 & $6,12 \pm 0,84$ & $6,13 \pm 1,22$ & $5,84 \pm 0,75$ & $5,83 \pm 1,04$ & $5,75 \pm 0,93$ & 0,273 \\
\hline PI 14 & $5,8 \pm 0,94$ & $5,77 \pm 1,36$ & $5,44 \pm 0,71$ & $5,52 \pm 1,21$ & $5,64 \pm 0,87$ & 0,529 \\
\hline PI 15 & $5,68 \pm 1,15$ & $5,87 \pm 1,25$ & $5,08 \pm 1,15$ & $5,41 \pm 0,91$ & $5,32 \pm 0,82$ & 0,049 \\
\hline PI 16 & $5,38 \pm 1,25$ & $5,43 \pm 1,48$ & $5,08 \pm 0,91$ & $4,45 \pm 1,45$ & $4,75 \pm 1,24$ & 0,006 \\
\hline PI 17 & $5,57 \pm 1,17$ & $5,87 \pm 1,41$ & $5,40 \pm 0.76$ & $5,00 \pm 1,28$ & $5,21 \pm 1,07$ & 0,046 \\
\hline PI 18 & $5,51 \pm 0,95$ & $5,80 \pm 1,10$ & $5,32 \pm 0,95$ & $5,03 \pm 1,18$ & $5,07 \pm 1,02$ & 0,021 \\
\hline PI 19 & $5,57 \pm 0,92$ & $6,03 \pm 1,07$ & $5,60 \pm 1,00$ & $5,10 \pm 1,11$ & $5,29 \pm 0.98$ & 0,006 \\
\hline PI 20 & $5,42 \pm 1,10$ & $5,40 \pm 1,35$ & $4,80 \pm 1,19$ & $5,07 \pm 1,19$ & $4,89 \pm 1,03$ & 0,085 \\
\hline PI 21 & $5,40 \pm 1,21$ & $5,30 \pm 1,37$ & $5,36 \pm 0.99$ & $5,21 \pm 1,05$ & $5,32 \pm 1,12$ & 0,964 \\
\hline
\end{tabular}

\subsection{Results of a Significant difference in achieving PSOs amongst Study Programs}

To investigate the differences in total average in achieving PSOs amongst study programs, an analysis statistic was used by using Tukey's HSD (honestly significant difference) test. It is found that the total average in achieving PSOs of Civil Engineering was different from Industrial engineering and Electrical engineering (Table 11); otherwise, the total average in achieving PSOs was not different amongst Civil
Engineering, Mechanical Engineering, and Environmental Engineering.

Investigation of more detail in achieving SOs, Turkey's HSD test was conducted for each SO, as shown in Table 12. From 7 SOs, only SO3 and SO7 were not significantly different amongst study programs. Industrial engineering's student was still low in achieving SO1, SO3, and SO5, whereas Environmental Engineering's student and Electrical Engineering's student were low in achieving SO2 and SO4, respectively.

Table 11 Tukey's HSD test for total average in achieving PSOs

\begin{tabular}{|l|c|c|c|}
\hline \multicolumn{1}{|c|}{ Study Programs } & \multirow{2}{*}{$\mathbf{N}$} & \multicolumn{2}{c|}{ Sub set for alpha = 0,05 } \\
\cline { 3 - 4 } & & $\mathbf{1}$ & $\mathbf{2}$ \\
\hline Industrial Engineering & 29 & 5,19 & \\
\hline Electrical Engineering & 25 & 5,21 & \\
\hline Environmental Engineering & 28 & 5,25 & 5,25 \\
\hline Mechanical Engineering & 65 & 5,62 & 5,62 \\
\hline Civil Engineering & 30 & & 5,71 \\
\hline Sig. & & $\mathbf{0 , 1 2 3}$ & $\mathbf{0 , 0 8 5}$ \\
\hline
\end{tabular}

\subsection{Discussion}

Based on the investigation, males and females were different learning experiences in achieving of PSOs and the same case with a study program where PEOs average were different amongst study program. It is shown that students do not all learn the same thing on the same day in the same way. This is a challenge for faculties to know students well enough to cater to their varying needs in the classroom [15]. To accomplish this situation, faculties should explore differentiated instructional strategies to enhance student learning experiences [16]. Tomlinson [17] describes differentiated instruction as a deliberate and conscious method of planning and teaching to address student variance and addresses the varied learning needs of students with the view of maximizing the potential of each learner. 
The ability of females through their learning experiences in achieving PSOs was not different from males in communication, teamwork skills, and experimentation. Learning experiences of males were still dominant in engineering foundation and engineering complex design, design, professional responsibility and broad education, and new knowledge. It is shown that male students are better at engineering knowledge than female students. According to [18] sex-related differences in cognitive, especially in math, were small.

Amongst study programs at the Faculty of Engineering, there were no differences in achieving
$\mathrm{SO} 3, \mathrm{SO} 5$, and $\mathrm{SO} 7$ through their learning experiences. Otherwise, for S01, S02, S04, and SO6, there were significantly different, especially for Industrial, Electrical, and Environmental engineering study programs. Faculties in three study programs could increase student achievement for SO1, SO2, and SO6 through student center learning methods for increasing the experiences of students. Even if the indirect assessment does not measure directly specified learning outcomes and is not direct in nature, one must not rush to judgment that the assessment is, therefore, indirect and is assessing learning [9]

Table 12 Tukey's HSD test for significantly different SOs amongst study programs

\begin{tabular}{|c|c|c|c|c|}
\hline \multirow[b]{2}{*}{ Student outcomes } & \multirow[b]{2}{*}{ Study Programs } & \multirow[b]{2}{*}{$\mathbf{N}$} & \multicolumn{2}{|c|}{ Sub set for alpha $=0,05$} \\
\hline & & & 1 & 2 \\
\hline \multirow[t]{6}{*}{ SO1 } & Industrial Engineering & 29 & 5,01 & \\
\hline & Electrical Engineering & 25 & 5,17 & 5,17 \\
\hline & Environmental Engineering & 28 & 5,21 & 5,21 \\
\hline & Mechanical Engineering & 65 & & 5,61 \\
\hline & Civil Engineering & 30 & & 5,62 \\
\hline & \multicolumn{2}{|l|}{ Sig. } & $\mathbf{0 , 8 3 1}$ & 0,144 \\
\hline \multirow[t]{6}{*}{ SO2 } & Environmental Engineering & 28 & 4,52 & \\
\hline & Industrial Engineering & 29 & 4,63 & 4,63 \\
\hline & Electrical Engineering & 25 & 4,64 & 4,64 \\
\hline & Civil Engineering & 30 & & 5,23 \\
\hline & Mechanical Engineering & 65 & & 5,33 \\
\hline & \multicolumn{2}{|l|}{ Sig. } & 0,949 & 0,056 \\
\hline \multirow[t]{6}{*}{ SO4 } & Electrical Engineering & 25 & 4,93 & \\
\hline & Industrial Engineering & 29 & 5,16 & \\
\hline & Environmental Eng. & 28 & 5,30 & 5,30 \\
\hline & Mechanical Engineering & 65 & 5,53 & 5,53 \\
\hline & Civil Engineering & 30 & & 5,87 \\
\hline & \multicolumn{2}{|l|}{ Sig. } & 0,076 & 0,099 \\
\hline \multirow[t]{6}{*}{ SO6 } & Industrial Engineering & 29 & 4,83 & \\
\hline & Environmental Engineering & 28 & 5,01 & 5,01 \\
\hline & Electrical Engineering & 25 & 5,27 & 5,27 \\
\hline & Mechanical Engineering & 65 & 5,49 & 5,49 \\
\hline & Civil Engineering & 30 & & 5,70 \\
\hline & \multicolumn{2}{|l|}{ Sig. } & 0,091 & 0,069 \\
\hline
\end{tabular}

\section{CONCLUSION}

Learning experiences of Faculty of Engineering's students in achieving PSOs were different between males and females. Females were still low to attain SO1, SO2, SO4, and SO6. Educators should encourage females in the class and find innovation in teaching and learning for them. The total average of achieving PSOs were no differences between Civil Engineering, 
Mechanical Engineering, and Environmental Engineering. Industrial Engineering was low in achieving SO1, SO4, and SO6, whereas Electrical Engineering and Environmental Engineering were low in achieving $\mathrm{SO} 4$ and $\mathrm{SO} 2$, respectively, through their experiences. It can be noted for faculties at the study programs to increase and develop innovation in teaching and learning methods. Even though indirect assessment methods do not measure specified learning outcomes, but they are assessment about learning.

\section{ACKNOWLEDGMENTS}

The authors gratefully acknowledge the financial support of The Institute of Educational Development and Quality Assurance Universitas Andalas through the research scheme in 2020.

\section{REFERENCES}

[1] ABET, Criteria for accrediting engineering program 2020-2021, ABET Engineering Accreditation Commission, Baltimore, MD, 2019.

[2] G. Folley, Dimension of adult learning: Adult education and training in a global era, Open University Press, Austria, 2004.

[3] M. Nehari and H. Bender, Meaningfulness of a learning experience: A measure for educational outcomes in higher education, Higher Education, Vol 7, 1978, pp. 1-11. DOI: https://doi.org/10.1007/BF00129786

[4] J. B. Biggs, Individual differences in study processes and the quality of learning outcomes, Higher Education, Vol. 8 (4), 1979, pp. 381394. DOI: $\underline{10.1007 / \mathrm{BF} 01680526}$

[5] F. Marton and R. Säljö, On qualitative differences in learning: I-outcome and process , British Journal of Educational Physicology, Vol. 46, 1976, pp. 4-11.

DOI: https://doi.org/10.1111/j.20448279.1976.tb02304.x

[6] K. Trigwell and M. Prosser, Improving the quality of student learning: The influence of learning context and student approaches to learning on learning outcomes, Higher Education, Vol. 22, 1991, pp. 151-266.

[7] S. Qureshi and R. Ullah, Learning experiences of higher education: Approaches to learning as measures of quality of learning outcomes,
Bulletin of Education and Research, Vol. 36 (1), June 2014, pp. 79-100.

[8] P. Ramsden, Learning to teach in higher education, New York, NY: Routledge, 2003.

[9] M. Elbeck and D. Bacon, Toward universal definitions for direct and indirect assessment, Journal of Education for Business, Vol. 90 (5), pp. 1-6.

[10] T. Sitzmann, K. Elly, K. Brown, and K. Bauer, Self-assessment of knowledge: A cognitive learning or affective measure ?, Academy of Management Learning and Education, Vol. 9, pp. 169-191.

[11] A. Y. Kolb and D. A. Kolb, Learning styles and learning spaces: Enhancing experiential learning in hinger education, Academy of Management Learning and Education, Vol. 2 (2), 2005, pp. 193- 212 .

[12] P. L. Maky, Assessing for learning: Building a sustainable commitment across of institution, Stylus Publishing, 2004.

[13] E.G. Carmines and R. A. Zeller, In reliability and validity assessment (quantitative application in social science), New York, Sage Publication, 1979.

[14] K. Murphy and W. Balzer, Rate error and rating accuracy, Journal of Applied Psychology, Vol. 71, 1989, pp. 619-624.

[15] G. Gregory and L. Kusmich, Data driven differentiation in standars-based classroom, Corwin Press, 2004.

[16] S. Joseph, Strategies for enhancing student learning experiences in higer education, Caribbean Teaching Scholar, Vol. 3 (2), November 2013, pp. 97-109.

[17] C. A. Tomlinson, How to differentiate instruction in mixed-ability classrooms, Alexandria, Virginia: ASCD, 2001.

[18] A. R. Delgado and G. Prieto, Cognitive mediators and sex-related differences in mathematics, Intelligence, Vol. 32, 2004, pp. 25-32. DOI: https://doi.org/10.1016/S0160-2896(03)00061-8 